\title{
INTENSITAS SERANGAN AKIBAT HAMA PEMAKAN DAUN SETELAH APLIKASI EKSTRAK DAUN KIRINYUH (Chromolaena odorata) PADA TANAMAN SAWI (Brassica juncea L.)
}

\author{
Finka Bella Palit ${ }^{1)}$, Henny Lieke Rampe ${ }^{1)}$, Marhaenus Rumondor ${ }^{1)}$ \\ ${ }^{1)}$ Program Studi Biologi, FMIPA Universitas Sam Ratulangi Manado \\ e-mail : finkabella02@gmail.com; Hennyrampe@unsrat.ac.id ; \\ Marhaenusrumondor66@unsrat.ac.id
}

\begin{abstract}
ABSTRAK
Penelitian ini bertujuan untuk mengevaluasi intensitas serangan akibat hama pemakan daun setelah aplikasi ekstrak daun kirinyuh pada tanaman sawi. Penelitian ini dilaksanakan di lahan percobaan di Kelurahan Lansot Kecamatan Tomohon Selatan Kota Tomohon pada bulan Desember 2018 - Februari 2019. Penelitian ini menggunakan rancangan acak lengkap (RAL) yang terdiri dari 4 perlakuan konsentrasi ekstrak daun kirinyuh yaitu $\mathrm{K}_{0}$ (kontrol) $=0 \mathrm{~g} / \mathrm{L}$ air, $\mathrm{K}_{1}$ $=100 \mathrm{~g} / \mathrm{L}$ air, $\mathrm{K}_{2}=200 \mathrm{~g} / \mathrm{L}$ air, dan $\mathrm{K}_{3}=300 \mathrm{~g} / \mathrm{L}$ air. Intensitas serangan diamati berdasarkan luas area daun yang dirusak oleh hama pemakan daun pada daun sawi setelah aplikasi ekstrak daun krinyuh. Hasil penelitian menunjukkan bahwa pemberian ekstrak daun kirinyuh berpengaruh nyata terhadap intensitas serangan pada tanaman sawi dan konsentrasi ekstrak daun kirinyuh yang dapat menekan serangan hama pemakan daun yaitu yang tertinggi pada perlakuan $\mathrm{K}_{3}(300 \mathrm{~g} / \mathrm{L}$ air).
\end{abstract}

Kata kunci: Tanaman sawi (Brassica juncea L.), intensitas serangan, tumbuhan kirinyuh

(Chromolaena odorata)

\section{THE ATTACK INTENSITY DUE TO LEAF-EATING PESTS AFTER APPLICATION OF KIRINYUH (Chromolaena odorata L.) LEAF EXTRACT ON MUSTARD GREEN (Brassica juncea L.)}

\begin{abstract}
This study aimed to evaluate the intensity of the attack due to leaf-eating pests after the application of kirinyuh leaf extract on mustard greens. This research was carried out on experimental fiel in Lansot Sub-District, South Tomohon District, Tomohon City in December 2018-February 2019. This study was used a completely randomized design consisting of 4 treatments of kirinyuh leaf extract concentration, namely $\mathrm{K}_{0}$ (control) $=0 \mathrm{~g} / \mathrm{L}$ water, $\mathrm{K}_{1}=100 \mathrm{~g} /$ $\mathrm{L}$ water, $\mathrm{K}_{2}=200 \mathrm{~g} / \mathrm{L}$ water, and $\mathrm{K}_{3}=300 \mathrm{~g} / \mathrm{L}$ water. The intensity of the attack was observed based on the area of leaf damaged by pest. The results showed that the application of kirinyuh leaf extract significantly affected the intensity of attacks on mustard greens and the concentration of kirinyuh leaf extract which was able to suppress leaf-eating pests which was the highest in the $\mathrm{K}_{3}$ treatment $(300 \mathrm{~g} / \mathrm{L}$ water $)$.
\end{abstract}

Keywords: Mustard greens (Brassica juncea L.), intensity of attack, Kirinyuh

(Chromolaena odorata)

Article History:

Received: July 11, 2019

Accepted: July 24, 2019

Published: July 25, 2019

\section{PENDAHULUAN}

Tanaman sawi merupakan tanaman yang memiliki nilai ekonomis tinggi, termasuk dalam suku Brassicaceae, banyak ditanam di dataran rendah maupun tinggi
(Rukmana, 2007). Tanaman sawi tergolong dalam tanaman yang toleran terhadap suhu tinggi (panas). Kebutuhan tanaman sawi sebagai sumber zat gizi semakin meningkat dikalangan masyarakat, seiring dengan meningkatnya jumlah penduduk saat ini 
(Rukmana, 2002).

Berdasarkan data Anonim (2014), produksi sawi di Indonesia dari tahun 2011 2013 mengalami peningkatan. Produksi sawi tahun 2011 yaitu 580.969 ton, tahun 2012 yaitu 594.911 ton, dan tahun 2013 yaitu 635.728 ton. Produksi sawi pada tahun 2014 mengalami penurunan yaitu 602.648 ton. Penurunan hasil produksi salah satunya disebabkan oleh gangguan Organisme Pengganggu Tanaman (OPT) berupa hama (Fajri et al., 2017). Berdasarkan data Anonim (2016) di Sulawesi Utara, produksi sawi pada tahun 2014 - 2016 mengalami peningkatan. Pada tahun 2014 yaitu 64.394 ton, tahun 2015 yaitu 162.574 ton, dan tahun 2016 yaitu 282.616 ton.

Pengendalian OPT umumnya dilakukan dengan menggunakan pestisida sintetik (kimia). Penggunaan pestisida sintetik dianggap lebih efektif, praktis dan dari segi ekonomi lebih menguntungkan. Penggunaan pestisida yang berlebihan dapat memberi dampak negatif bagi kehidupan baik tanaman, hewan, maupun manusia. Dampak negatif penggunaan pestisida sintetik berupa polusi lingkungan berupa kontaminasi pada tanah, air, dan udara, serangga hama menjadi resisten, resurgensi dan toleran terhadap pestisida, serta dampak negatif lainnya. Salah satu cara menekan OPT dalam budidaya tanaman sayuran dilakukan dengan menggunakan pestisida nabati (Kardinan, 2011).

Pestisida nabati merupakan suatu pestisida yang dibuat dari tumbuh-tumbuhan yang residunya mudah terurai di alam (Samsudin, 2008). Pestisida nabati tergolong dalam metabolit sekunder. Pestisida nabati juga segolongan dengan insektisida nabati (Pandiangan, 2009). Tumbuhan yang dapat digunakan sebagai pestisida nabati antara lain tembakau, mimba, mindi, mahoni, srikaya, sirsak, tuba, dan juga berbagai jenis gulma seperti babadotan dan kirinyuh (Samsudin, 2008).

Kirinyuh termasuk dalam suku Asteraceae merupakan gulma padang rumput yang penyebarannya sangat luas di Indonesia (Thamrin et al., 2013). Kirinyuh mengandung senyawa metabolit sekunder yaitu alkohol, flavanon, flavos, khalkon, asam aromatik dan minyak esensial. Minyak esensial dari daun diduga dapat menekan pertumbuhan beberapa jamur pathogen tanaman seperti jamur Pyricularia grisea, Fusarium oxysporum dan Phytophthora nicotiana (Santosh dan Gouri, 2010).

Hama pemakan daun yang menyerang tanaman hortikultura sangat bervariasi bergantung dari jenis spesies dan faktor abiotik, demikian juga untuk hama tanaman sawi. Aplikasi pestisida nabati akan mempengaruhi perkembangan hama pemakan daun termasuk tingkat serangannya. Penelitian ini akan mengkaji intensitas serangan hama pemakan daun setelah aplikasi ekstrak daun kirinuh pada tanaman sawi. Penelitian ini bertujuan untuk mengevaluasi intensitas serangan akibat hama pemakan daun setelah aplikasi ekstrak daun kirinyuh (Chromolaena odorata) pada tanaman sawi (Brassica juncea)

\section{BAHAN DAN METODE}

\section{Tempat dan Waktu Penelitian}

Penelitian dilaksanakan di lahan percobaan di Kelurahan Lansot Kecamatan Tomohon Selatan Kota Tomohon dan dilaksanakan pada bulan Desember 2018 Februari 2019.

\section{Metode Penelitian}

Penelitian ini menggunakan Rancangan Acak Lengkap (RAL) yang terdiri dari empat perlakuan konsentrasi ekstrak daun kirinyuh sebagai berikut : $\mathrm{K}_{0}$ $($ kontrol $)=0 \mathrm{~g} / \mathrm{L}$ air, $\mathrm{K}_{1}=100 \mathrm{~g} / \mathrm{L}$ air, $\mathrm{K}_{2}=$ $200 \mathrm{~g} / \mathrm{L}$ air, dan $\mathrm{K}_{3}=300 \mathrm{~g} / \mathrm{L}$ air, masingmasing perlakuan diulang tiga kali.

\section{Persiapan media tanam dan penyemaian benih sawi}

Dibuat 12 bedengan dengan ukuran panjang $100 \mathrm{~cm}$ dan lebar $50 \mathrm{~cm}$. Selanjutnya penentuan perlakuan berdasarkan undian pada bedengan. Setiap bedengan dibuat delapan lubang tanam dengan jarak antara lubang tanam $25 \mathrm{~cm}$. Benih sawi hijau jenis espana yang diperoleh dari toko benih direndam dalam air selama satu jam dan selanjutnya disemai dibedengan yang telah dipersiapkan sebanyak lima benih per lubang tanam, kemudian disiram dengan air. 


\section{Penjarangan Benih}

Bibit sawi yang sudah berumur 14 HST (Hari Sesudah Tanam) atau berdaun dua helai, dilakukan penjarangan yaitu dengan cara mencabut benih yang tumbuh dan menyisakan satu tanaman per lubang tanam (Samadi, 2017).

\section{Pemeliharaan Tanaman Sawi}

Pemeliharaan tanaman sawi yaitu dengan melakukan penyiraman tanaman, penyiangan gulma (rumput) dan pemberian pupuk. Untuk pemupukkan pada tiap bedeng diberi pupuk urea $32 \mathrm{~g}$, TSP $24 \mathrm{~g}$, dan $\mathrm{KCl}$ 16 g. Pemupukkan dilakukan pada saat tanaman sawi berumur 14 HST dan 28 HST.

\section{Pembuatan Ekstrak Daun Kirinyuh}

Daun kirinyuh diambil dari Kelurahan Uner Kecamatan Kawangkoan, daun kirinyuh yang diambil adalah bagian daun yang mulai membesar, kemudian daun dicuci bersih, lalu dikering-anginkan. Untuk perlakuan $\left(\mathrm{K}_{1}\right)$ yaitu sebanyak $100 \mathrm{~g}$ daun kirinyuh dipotong sekitar $2 \mathrm{~cm}$, kemudian ditambahkan aquades secukupnya, lalu diblender. Setelah halus kemudian disaring, ampas selanjutnya diblender dan disaring kembali sampai tersisa serat-serat tumbuhan. Supernatan kemudian digenapkan menjadi 1 $\mathrm{L}$ dengan air. Untuk $\mathrm{K}_{2}$ dan $\mathrm{K}_{3}$ prosedurnya sama hanya berat daunnya yang berbeda yaitu $\mathrm{K}_{2}$ sebanyak $200 \mathrm{~g}$, dan $\mathrm{K}_{3}$ sebanyak $300 \mathrm{~g}$ daun kirinyuh.

\section{Aplikasi Ekstrak}

Aplikasi ekstrak daun kirinyuh sesuai perlakuan dengan cara menyemprotkan konsentrasi ekstrak yang telah disiapkan pada semua permukaan bagian tubuh tanaman. Aplikasi ekstrak dilakukan setiap 10 hari yaitu pada saat tanaman berumur 16 HST, 26 HST dan 36 HST.

\section{Pengamatan}

Parameter yang diamati adalah menghitung intensitas serangan akibat hama pemakan daun yaitu dengan menggunakan rumus yang dikemukakan oleh Natawigena (1982) yang telah dimodifikasi adalah sebagai berikut :
$\mathrm{P}=\frac{a}{b} \times 100 \%$

Dimana:

$\mathrm{P}=$ Intensitas serangan

$\mathrm{a}=$ Luas daun yang diserang

$\mathrm{b}=$ Luas daun yang tanaman yang diamati

Untuk menentukan intensitas serangan digunakan kertas millimeter block, pengamatan dilakuan saat tanaman berumur 42 HST. Untuk mengetahui skala tiap kategori serangan dapat dilihat pada tabel 1 .

Tabel 1. Penentuan skala tiap kategori serangan

\begin{tabular}{ccc}
\hline $\begin{array}{c}\text { Nilai } \\
\text { Skala }\end{array}$ & Presentasi & $\begin{array}{c}\text { Kategori } \\
\text { Serangan }\end{array}$ \\
\hline $\mathbf{0}$ & - & Normal \\
$\mathbf{1}$ & $>0-25$ & Ringan \\
$\mathbf{2}$ & $>25-50$ & Sedang \\
$\mathbf{3}$ & $>50-75$ & Berat \\
$\mathbf{4}$ & $>75$ & Sangat berat \\
\hline
\end{tabular}

\section{Analisis Data}

Data yang diperoleh dianalisis dengan uji Analisis varians (ANAVA), dan dilanjutkan dengan uji Beda Nyata Terkecil (BNT) pada taraf 0,05 (Hanafiah, 2004).

\section{HASIL DAN PEMBAHASAN}

Data rerata intensitas serangan tanaman sawi dari setiap ulangan ditunjukkan pada Tabel 2.

Tabel 2. Rerata Intensitas Serangan Hama Pemakan Daun pada Tanaman Sawi

\begin{tabular}{cccccc}
\hline $\begin{array}{l}\text { Perla- } \\
\text { kuan }\end{array}$ & \multicolumn{3}{c}{ Ulangan } & $\begin{array}{c}\text { Juml- } \\
\text { ah }\end{array}$ & $\begin{array}{c}\text { Rerata } \\
(\%)\end{array}$ \\
\cline { 2 - 4 } & 1 & 2 & 3 & & \\
\hline $\mathrm{K}_{0}$ & 6,74 & 6,43 & 6,51 & 19,68 & $6,56 \pm 0,16$ \\
$\mathrm{~K}_{1}$ & 4,22 & 4,49 & 4,52 & 13,23 & $4,41 \pm 0,16$ \\
$\mathrm{~K}_{2}$ & 2,01 & 1,78 & 1,92 & 5,71 & $1,90 \pm 0,12$ \\
$\mathrm{~K}_{3}$ & 0,46 & 0,53 & 0,52 & 1,51 & $0,50 \pm 0,04$ \\
\hline
\end{tabular}

Berdasarkan Tabel 2, diperoleh nilai rerata intensitas serangan yang paling tinggi pada perlakuan $\mathrm{K}_{0}$ (kontrol) yaitu $(6,56 \pm 0,16) \%$ dan yang paling rendah pada perlakuan $\mathrm{K}_{3}$ yaitu $(0,50 \pm 0,04) \%$. Hal ini 
menunjukkan bahwa semakin tinggi konsentrasi ekstrak daun kirinyuh, maka tingkat kerusakan daun pada tanaman sawi semakin rendah.

Tabel 3. Hasil Analisis Varian Intensitas Serangan Hama Pemakan Daun pada Tanaman $\underline{\text { Sawi }}$

\begin{tabular}{lccclc}
\hline SK & DB & JK & KT & $\begin{array}{l}\text { F } \\
\text { Hitung }\end{array}$ & $\begin{array}{c}\text { F } \\
\mathbf{0 , 0 5}\end{array}$ \\
\hline Perlakuan & 3 & 64,87 & 21,62 & $1201,11^{*}$ & 4,07 \\
Galat & 8 & 0,15 & 0,018 & & \\
Total & 11 & 65,02 & & & \\
\hline
\end{tabular}

Berdasarkan Tabel 3, diperoleh nilai F hitung yaitu 1201,11 lebih besar dari nilai F tabel(5\%) yaitu 4,07, menunjukkan bahwa pemberian ekstrak daun kirinyuh berpengaruh nyata terhadap intensitas serangan hama pemakan daun pada tanaman sawi.

Berdasarkan data pada Tabel 4, antara perlakuan $\mathrm{K}_{0}-\mathrm{K}_{1}, \mathrm{~K}_{0}-\mathrm{K}_{2}, \mathrm{~K}_{0}-\mathrm{K}_{3}, \mathrm{~K}_{1}-$ $\mathrm{K}_{2}, \mathrm{~K}_{1}-\mathrm{K}_{3}$, dan $\mathrm{K}_{2}-\mathrm{K}_{3}$ berbeda nyata pada taraf uji 0,05 dengan nilai $\mathrm{BNT}>0,253$.

Tabel 4. Hasil uji Beda Nyata Terkecil (BNT)

\begin{tabular}{ccc}
\hline Perlakuan & Rerata & $\begin{array}{c}\text { Notasi BNT } \\
\mathbf{0 , 0 5}(=\mathbf{0 . 2 5})\end{array}$ \\
\hline $\mathbf{K}_{\mathbf{0}}$ & 6,56 & $\mathrm{a}$ \\
$\mathbf{K}_{\mathbf{1}}$ & 4,41 & $\mathrm{~b}$ \\
$\mathbf{K}_{\mathbf{2}}$ & 1,90 & $\mathrm{c}$ \\
$\mathbf{K}_{\mathbf{3}}$ & 0,50 & $\mathrm{~d}$ \\
\hline
\end{tabular}

Ket. Huruf yang berbeda dalam satu kolom menunjukkan berbeda nyata pada taraf nyata $5 \%$

Kirinyuh adalah gulma berbentuk semak berkayu yang dapat berkembang cepat sehingga sulit dikendalikan. Gulma ini dapat dijadikan sebagai insektisida nabati karena mengandung senyawa metabolit sekunder salah satunya adalah Pryrolizidine alkaloids yang bersifat racun terhadap serangga (Thamrin, et al. 2013). Data hasil penelitian Frastika (2017) menunjukkan bahwa ekstrak daun kirinyuh mengandung senyawa metabolit sekunder yaitu saponin, tannin, flavonoid, alkaloid, dan fenolik.

Hasil pengujian penggunaan ekstrak daun kirinyuh Tabel 1, diperoleh semakin tinggi konsentrasi ekstrak, maka semakin rendah intensitas serangan hama pada tanaman sawi. Hal ini karena senyawa kimia yang terkandung dalam ekstrak kirinyuh semakin banyak sehingga menyebabkan tingkat kerusakan daun berkurang. Sejalan dengan Prijono (1999) dalam Yunia (2006) menyatakan bahwa semakin tinggi dosis yang digunakan, maka kandungan bahan dalam larutan juga lebih banyak sehingga daya racun dari pestisida nabati semakin tinggi. Asikin (2016) berpendapat bahwa kandungan yang dimiliki oleh ekstrak tumbuhan kirinyuh adalah terpenoid, tanin, saponin dan seskuiterpen. Senyawa senyawa fenol, triterpenoid, alkaloid dan steroid yang terdapat pada tumbuhan merupakan bahan aktif sebagai pengendali hama. Senyawa tersebut menyebabkan adanya aktifitas biologi yang khas seperti toksik menghambat makan, antiparasit, dan pestisida.

Hama yang ditemukan selama penelitian yaitu ulat tritip (Plutella xylostella) dan ulat grayak (Spodoptera litura) dapat dilihat pada Gambar 1 dan Gambar 2. Hama ini ditemukan pada pengamatan saat tanaman berumur 14 HST (hari sesudah tanam). Ulat tritip dan ulat grayak menyerang tanaman sawi dengan cara memakan daun hingga daun tampak berlubang (Gambar 3).
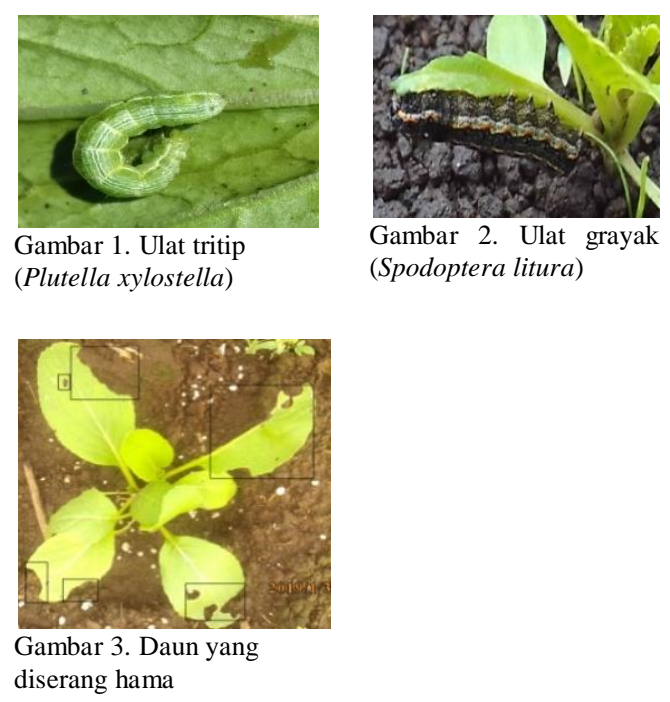

Pyrolizidine alkaloids termasuk alkaloida golongan metabolit sekunder (Pandiangan, 2009). Pyrolizidine alkaloids merupakan senyawa kimia aktif yang terkandung dalam tumbuhan kirinyuh dan memiliki sifat toksik, sebagai penghambat makan dan insektisida bagi serangga (Febrianti dan Rahayu, 2012 dalam Maheswari, 2018). Menurut Cahyadi (2009) 
senyawa alkaloid dan flavonoid dapat bertindak sebagai racun perut. Oleh karena itu, bila senyawa alkaloid dan flavonoid tersebut masuk ke dalam tubuh larva maka alat pencernaannya akan terganggu. Selain itu, senyawa tersebut menghambat reseptor perasa pada daerah mulut larva, mengakibatkan larva gagal mendapatkan stimulus rasa sehingga tidak mampu mengenali makanannya sehingga larva mati kelaparan. Menurut Sulistiyono (2004) dan Prabowo (2010) racun perut akan mempengaruhi metabolisme larva, racun akan masuk ke dalam tubuh dan diedarkan bersama darah. Racun yang terbawa darah akan mempengaruhi sistem saraf larva dan kemudian akan menimbulkan kematian.

Tanin berperan sebagai pertahanan tanaman terhadap serangga dengan cara menghalangi serangga dalam mencerna makanan. Tanin dapat mengganggu serangga dalam mencerna makanan karena tanin akan mengikat protein dalam sistem pencernaan menjadi terganggu. Selain itu tanin memiliki rasa pahit sehingga dapat menyebabkan mekanisme penghambatan makan pada hewan uji akan kelaparan dan akhirnya mati. (Yunita et al., 2009).

Seskuiterpenoid merupakan senyawa bioaktif yang mampu merusak sistem saraf pada serangga. Masuknya senyawa tersebut diketahui dapat menghambat bekerjanya enzim asetil-kolinesterase sehingga menyebabkan mortalitas pada rayap (Hadi, 2008). Hal tersebut mengakibatkan otot kejang, terjadi kelumpuhan dan berakhir dengan kematian. Kemungkinan seskuiterpenoid yang terkandung dalam ekstrak etanol daun kirinyuh juga dapat menyebabkan mortalitas pada wereng coklat (Asikin, 2016).

Berdasarkan kategori serangan hama pemakan daun menurut Natawigena (1982) pada tabel 2, hasil penelitian menunjukkan bahwa intensitas serangan yang terjadi pada 4 perlakuan yaitu $\mathrm{K}_{0}$ (Kontrol), $\mathrm{K}_{1}, \mathrm{~K}_{2}$ dan $\mathrm{K}_{3}$ mengalami rusak ringan dengan presentasi yang tidak terlalu jauh berbeda untuk masing-masing perlakuan. Kategori serangan ringan karena disebabkan selama penelitian adalah musim penghujan dimana hal tersebut rentan terhadap serangan hama dan penyakit. Sesuai dengan pernyataan Marwoto dan Indiati (2009) yang menyatakan bahwa hujan berpengaruh terhadap perkembangan dan aktivitas serangga hama. Hujan lebat akan menghanyutkan sebagian besar dari populasi serangga kecil dan lemah seperti kutu-kutu daun.

\section{KESIMPULAN DAN SARAN}

\section{Kesimpulan}

Pemberian ekstrak daun kirinyuh berpengaruh nyata terhadap intensitas serangan akibat hama pemakan daun setelah aplikasi ekstrak daun kirinyuh pada tanaman sawi dan Kosentrasi ekstrak daun kirinyuh yang dapat menekan serangan hama pemakan daun yaitu konsentrasi tertinggi pada perlakuan $\mathrm{K}_{3}(300 \mathrm{~g} / \mathrm{L}$ air).

\section{Saran}

Perlu dilakukan penelitian lanjutan dari ekstrak daun kirinyuh untuk melihat manfaat atau potensi lain dari daun kirinyuh selain berperan sebagai insektisida nabati.

\section{DAFTAR PUSTAKA}

Anonim. 2014. Statistik Produksi Hortikultura Tahun 2014. Badan Pusat Statistik, Jakarta.

Anonim. 2016. Produksi Tanaman Sayuran dan Buah-buahan Semusim 2016 di Sulawesi Utara. https://sulut.bps.go.id/dynamictable /2017/05/09/124/luas-panenproduksi-dan-hasil-per-hektartanaman-sayuran-dan-buah-buahansemusim-2015.html [ 1 November 2018].

Asikin, S. 2016. Dua Jenis Gulma sebagai Pestisida Nabati terhadap Ulat Krop Kubis (Crocidolomia pavartata). Prosiding Seminar Nasional Inovasi Teknologi Pertanian ; Banjarbaru, 20 Juli 2016. Hlm 880 - 892.

Cahyadi, R. 2009. Uji Toksitas Akut Ekstrak Etanol Buah Pare (Momordica charantia L.) Terhadap Larva Artemia Salina Leach dengan Metode Brine Shrimp Lethality Test (BST) [Skripsi]. Universitas Diponegoro, Semarang. 
Fajri, L., H. Tuti ., dan Hilda. 2017. Pengendalian Hama Ulat menggunakan Larutan Daun Pepaya dalam Peningkatan Produksi Sawi (Brassica juncea L.). Jurnal Agroekoteknologi 4 (1) : 69 - 76.

Frastika, D., Ramadhanil., dan Suwastika. 2017. Uji Efektivitas Ekstrak Daun Kirinyuh (Chromolaena odorata) sebagai Herbisida Alami terhadap Perkecambahan Biji Kacang Hijau (Vigna radiata) dan Biji Karuile (Mimosa invisa). Jurnal of Science and Techonology 6 (3) : 225 - 238.

Hadi, M. 2008. Pembuatan Kertas Anti Rayap Ramah Lingkungan dengan Memanfaatkan Ekstrak Daun Kirinyuh (Eupatorium odoratum). BIOMA 6 (2) : 12 - 18.

Hanafiah, A.K. 2004. Rancangan Percobaan, Edisi Ketiga. Raja Grafindo Persada, Jakarta.

Kardinan, A. 2011. Penggunaan Pestisida Nabati sebagai Kearifan Lokal dalam Pengendalian Hama dan Tanaman Menuju Sistem Pertanian Organik. Jurnal Pengembangan Inovasi Pertanian 4 (4) : 262 - 278.

Maheswari, P., I. N. Wijaya., dan M. Sritamin. 2018. Uji Efektivitas Beberapa Jenis Ekstrak Daun Tanaman terhadap Perkembangan Ulat Daun Kubis (Plutella xylostella L.) di Laboratorium. Jurnal Agroekoteknologi 7 (3) : 392 - 399.

Marwarto dan S. W. Indiati. 2009. Pengendalian Hama Kedelai pada Era Perubahan Iklim Global. IPTEK tanaman pangan 4 (1) : $94-103$.

Natawigena. 1982. Pestisida dan Kegunaannya. Universitas Padjajaran, Bandung.

Pandiangan, D. 2009. Produksi Metabolit Sekunder Alkaloid Secara in vitro. UNPAD Press, Bandung.

Prabowo, H. 2010. Pengaruh Ekstrak Bunga Oleander (Nerium oleander L.) terhadap Mortalitas Hama Tanaman Jarak Pagar (Selenothrips rubrociuctus Giard). Makalah Seminar Nasional Biologi. Fakultas Biologi, UGM.
Rukmana, R. 2002. Bertanam Kubis. Kanisius, Yogyakarta.

Rukmana,R. 2007. Bertanam Petsai dan Sawi. Kanisius, Yogyakarta.

Samadi, B. 2017. Teknik Budidaya Sawi dan Pak Choy. Pustaka Mina, Depok Timur.

Samsudin. 2008. Pengendalian Hama dengan Insektisida Botani. Lembaga Pertanian Sehat. www.pertaniansehat.or.id. [1 November 2018].

Santosh, dan Gouri. 2010. Qualitative Phytochemical Analysis and Investigation of Anthelmintic and Wound Healing Potentials of Various Extracts of Chromolaena odorata linn. Collected From The Locality of Mohuda Village, Berhampur (South orissa). International Journal of Pharmaceutical Sciences Review and Research 1 (2) : 122 - 126.

Sulistiyono, L. 2004. Dilema Penggunaan Pestisida dalam Sistem Pertanian Tanaman Hortikultura di Indonesia. Makalah Pengantar ke Falsafah Sains. Sekolah Pascasarjana, IPB Bogor, Bogor.

Thamrin, M. S., Asikin., dan M. Willis. 2013. Tumbuhan Kirinyuh Chromolaena Odorata (L) (Asteraceae: Asterales) sebagai Insektisida Nabati untuk mengendalikan Ulat Grayak Spodoptera Litura. Jurnal Litbang Pertanian 32 (3): 112 - 121.

Yunia, N. 2006. Aktivitas Insektisida Campuran Ekstrak Empat Jenis Tumbuhan terhadap Larva Crocidoloma pavonana F. (Lipedoptera : Pyralidae) [Skripsi]. IPB, Bogor.

Yunita, E.A., Nanik dan N. H. Jafron. 2009. Pengaruh Ekstrak Daun Tekelan (Eupatorium riparium) terhadap Mortalitas dan Perkembangan Larva Aedes aegypti. BIOMA 2 (1) : 11 17. 